\title{
Haematology, serum biochemistry and organ weight changes of wistar rats fed processed dehulled jack bean (Canavalia ensiformis)
}

Amusa $^{1}$, H. O. Kehinde ${ }^{2}$, R. A., Atoyebi ${ }^{2}$, R. O. and $\mathrm{Abu}^{2 *}$, O. A.

${ }^{1}$ Department of Animal Health and Production Oyo State College of Agriculture, Igboora,

Oyo State, Nigeria

${ }^{2}$ Department of Animal Science, University of Ibadan, Ibadan Nigeria

*Corresponding authors E-mail: oa.abu@,mail.edu.ui.ng

\begin{abstract}
A total of fifty Wistar albino rats weighing 50-60g were randomly allocated to five dietary treatments in a completely randomized design to investigate the haematology, serum biochemistry and organ weight changes on diets containing processed dehulled jack bean. Four diets containing 10\% crude protein were formulated to contain casein (T1)-control diet, dehulled jack bean soaked in filtrate obtained from $24 \mathrm{hr}$ water-steeped whole maize grains (T2), dehulled jack bean soaked in lye solution (T3), dehulled jack bean boiled for 15 minutes (T4) while a protein free diet served as a negative control (T5). The feeding trial lasted for 28days after which four rats per treatments were sampled to evaluate haematological and serum biochemical indices while three rats per treatment were sacrificed by cervical decapitation and the heart, liver, kidneys and the lungs removed and weighed separately. Haemoglobin (Hb), white blood cells (WBC), eosinophil and Mean Corpuscular Haemoglobin Concentration $(M C H C)$ were not affected by dietary treatments while the packed cell volume, red blood cells, lymphocytes, neutrophils, monocytes, Mean Corpuscular Volume (MCV) and Mean Corpuscular Haemoglobin (MCH) were significantly affected $(P<0.05)$ by dietary treatments. Rats on T4 had the highest PCV $(47.00 \%)$, and neutrophil (25.67\%) values, while rat on control had the highest value of RBC $5.95\left(\times 10^{6} / \mathrm{mm}^{3}\right)$. Rats on $\mathrm{T} 2$ had the highest lymphocyte $(80.33 \%)$ and monocyte $(3.50 \%)$ values, while the lowest value was for rats T4 (73.25\%) and T3 (2.00\%). Rats on T3 had the highest MCV (1.57fl) and MCH (0.40pg) values the total protein and alkaline phosphatise $(A L P)$ were similar $(P>0.05)$ for all group, while the albumin, globulin, cholesterol, Aspartate aminotransferase (AST) and Alanine aminotransferase (ALT) were influence by dietary treatments $(P<0.05)$. Albumin values ranges from $5.83 \mathrm{~g} / \mathrm{dl}$ to $7.68 \mathrm{~g} / \mathrm{dl}$ with rats on T4 having the highest albumin value $(7.68 \mathrm{~g} / \mathrm{dl})$. Globulin value for rats on T4 is significantly $(P<0.05)$ different from rats on T1, T2, T3, and T5 with rats on T3 having the highest value (3.42). Rats on $T 1$ had the highest Cholesterol $(55.37 \mathrm{mg} / \mathrm{dl})$ and $A L T(17.49 I U / L)$ value, while Rats on $T 2$ had the highest AST (16.13IU/L) value. Kidney weights were similar for all group $(P>0.05)$ while the liver, lungs and heart relative weights were significantly affected $(P<0.05)$ by dietary treatments. Rats on control diet had the lowest relative weight for liver (3.74), lungs (1.03), kidney (0.92) and heart (0.49). Rats on T3 and T5 had the highest value for heart weight (0.75) and liver weight (5.67)while rats on T4 had the highest value for lungs (1.59).Rats fed dehulled jack bean seed soaked in ogi liquor showed slight improvement on haematological, serum profile and organ weight changes over those fed lye soaked jack bean and boiled for 15minutes. However, all the processing methods were ineffective when compared to the performance of ratfed casein based diets.
\end{abstract}

Keywords: Jack bean, rats, haematology, blood serum, carcass 
Introduction

The interest in unconventional feed sources was borne out of zeal to find alternative feed ingredients to replace expensive soya bean meal in the diets of animals particularly in developing countries where there has been an acute shortage of animal protein (Fasuyi, 2005). The low protein intake had been attributed to low level of animal protein production and high cost of animal products (Ani and Adiegwu, 2005) hence the need to explore every possibility of incorporating unconventional protein feedstuffs into livestock feed in order to reduce the cost of feed and maximize returns. One such alternative ingredient with potentials for substituting expensive soybean meal in livestock feeding is jack bean (Canavalia ensiformis.) due to its high protein and carbohydrate contents (Udedibie and Carlini, 1998).

Jack bean (Canavalia ensiformis) is an underutilized legume with crude protein content of about $22-29 \%$ and has good amino acid profile (Udedibie et al., 1990). However, its utilization in livestock feed is limited by presence of anti-nutritional factors such as haemaglutinins and protease inhibitors (Laurena et al., 1994),lectins, canavanine, Con canavanine A and other non- protein amino acid (Arora, 1995, D'Mello, 1995a,b) as well as tannins, phytates and canavanine (Siddhuraju and Becker, 2001). Much emphasis has been placed on processing of legume seeds by toasting, boiling and dehulling or soaking as a means of eliminating these factors (Amaefule and Nwagbara, 2004), but these processing methods are cumbersome and costly, thus limiting their use by farmers and feed millers in Nigeria. The aim of this study was to examine the effect of processed jack bean in cheaply and less cumbersome methods such soaking in acidic, alkaline and boiled on the haematological parameters, serum biochemistry indices and organ weight changes of Wistar rats.

\section{Materials and Methods \\ Experimental site}

The experiment was carried out at the Rat House, Department of Animal Science, University of Ibadan. The position of Ibadan is Latitude: $7^{\circ} 23.2668^{\prime} \mathrm{N}$ Longitude: $3^{\circ} 53.7834^{\prime} \mathrm{E}$ of about 255 meters above sea level as referenced by WGS 84 is the latest revision of the World Geodetic System.

Collection of and pretreatment of seeds

Jack beans were purchased from Bodija market in Ibadan. The beans were soaked at the rate of $1 \mathrm{~kg} / 1.5 \mathrm{~L}$ of water for 12 hours to facilitate manual dehulling of the soaked beans.

Processing of jack bean seed

Dehulled jack bean seed was soaked in raw filtrate obtained from water steeped whole maize grains at the rate of $1 \mathrm{~kg} / 3 \mathrm{~L}$ for $24 \mathrm{hrs}$ (pH3.6-4.3) or $0.5 \%$ of cocoa pod ash solution ( $\mathrm{pH}$ 6.3-10.9) for the next 48hrs. Another batch of the dehulled jack bean boiled at $100^{\circ} \mathrm{C}$ at 1 atmosphere for $15 \mathrm{~min}$. The samples were sun-dried at $32-33^{\circ} \mathrm{C}$ for 3 days, milled and then included in the diet accordingly

\section{Experimental diets}

Four dietary treatments were compounded to supply $10 \%$ crude protein on dry matter basis while the fifth diet was protein free (Table 1). A basal diet T1 with casein served as the control, the rats on $\mathrm{T} 2$ received dehulled jack bean soaked in raw ogi maize liquor, rats on $\mathrm{T} 3$ received dehulled jack been soaked in lye solution, and those on T4 received dehulled jack bean boiled for 15 minutes while $\mathrm{T} 5$ received a protein free diet. 
Amusa. Kehinde, Atoyebi and Abu

Table 1. Gross composition of experimental diets (\%)

\begin{tabular}{|c|c|c|c|c|c|}
\hline Ingredients & $\mathrm{T} 1$ & $\mathrm{~T} 2$ & $\mathrm{~T} 3$ & $\mathrm{~T} 4$ & T5 \\
\hline Corn starch & 55.00 & 24.70 & 22.60 & 26.70 & 65.00 \\
\hline Casein & 10.00 & - & - & - & - \\
\hline Jack bean meal & - & 40.30 & 42.40 & 38.30 & - \\
\hline Sucrose & 12.25 & 12.25 & 12.25 & 12.25 & 12.25 \\
\hline Groundnut oil & 8.00 & 8.0 & 8.0 & 8.0 & 8.0 \\
\hline Glucose & 6.0 & 6.0 & 6.0 & 6.0 & 6.0 \\
\hline Non-nutritive cellulose & 5.0 & 5.0 & 5.0 & 5.0 & 5.0 \\
\hline Oyster shell & 1.0 & 1.0 & 1.0 & 1.0 & 1.0 \\
\hline Di calcium phosphate & 2.0 & 2.0 & 2.0 & 2.0 & 2.0 \\
\hline Table salt & 0.25 & 0.25 & 0.25 & 0.25 & 0.25 \\
\hline Vit-min premix* & 0.50 & 0.50 & 0.50 & 0.50 & 0.50 \\
\hline Total & 100 & 100 & 100 & 100 & 100 \\
\hline
\end{tabular}

Experimental design and animal management

Fifty 3-4 weeks old Wistar rats of an average initial weight of 50-60g were collected from the stock of Animal House of the Department of Physiology, University of Ibadan and taken to the Rat House, Department of Animal Science, University of Ibadan. The rats were weighed and randomly assigned on the basis of body weight into five dietary treatments of ten rats each in a completely randomized block design experiment. Rats in each experimental animal group were housed individually in well-ventilated stainless metabolic cages and allowed access to one of the five experimental diets. The trial commenced after a 5-day acclimatization period and lasted for 28-days. Water and diets were allowed ad libitum. Weight of animals was taken at the beginning and thereafter at weekly intervals.

Blood collection and analysis

At day 28 of the feeding trial, $2 \mathrm{ml}$ blood samples were collected from four rats per treatments into sample bottles containing
Ethylene Diamine Tetra- Acetate (EDTA) as anticoagulant to determine the haematological components. The blood samples were assayed for packed cell volume (PCV), haemoglobin $(\mathrm{Hb})$,Differential leukocyte counts, red blood cells (RBC), white blood cells (WBC), Mean Corpuscular Volume (MCV), Mean Corpuscular Haemoglobin $(\mathrm{MCH})$ and Mean Corpuscular Haemoglobin Concentration (MCHC) were determined using the appropriate formulae (Jain, 1996). Another $2 \mathrm{ml}$ was collected into a sterile sample bottles' without coagulant to determine the serum biochemical components. The blood samples were assayed forSerum total protein, albumin, Globulin, Cholesterol, aspartate aminotransferase (AST), alanine aminotransferase (ALT), Alkaline phosphatase (ALP). The rats were kiled by neck decapitation and the heart, lungs liver and kidney were removed and weighed separately.

Statistical analysis

Data collected was subjected to statistical 
analysis of variance (ANOVA) using SAS (1999) version and means separated by Duncan Multiple Range Test of the same statistical package.

\section{Results and discussion}

The proximate and fibre fractions composition of experimental diets are presented in Table 2. Dehulled jack bean soaked in lye solution had the highest crude protein (14.30) and ash (6.60) than the other diets, while the protein free diet had the highest ether extract (8.50). The results of the haematological indices, serum biochemical profile and organ weight changes of rats fed processed jack bean are shown in Table 3, 4 and 5 respectively. Haemoglobin, white blood cells (WBC), eosinophil and Mean Corpuscular Haemoglobin Concentration (MCHC) were not affected by dietary treatments. The packed cell volume, red blood cells, lymphocyte, neutrophils, monocyte, Mean Corpuscular Volume (MCV) and Mean Corpuscular Haemoglobin( $\mathrm{MCH})$ were significantly affected $(\mathrm{P}>0.05)$ by dietary treatments. Rats on boiled dehulled jack bean had the highest PCV value of (47.00), and neutrophil (25.67), while rat on control had the highest value of RBC (5.95). Rats on T2 had the highest lymphocyte and monocyte value of (80.33) and (3.50) while the lowest value was in T4 (73.25) and T3
(2.00). MCV and $\mathrm{MCH}$ of rats on $\mathrm{T} 3$ is significantly $(\mathrm{P}<0.05)$ different from other treatment group with $\mathrm{T} 3$ having the highest MCV (1.57) and MCH (0.40) values. The total protein and alkaline phosphatase (ALP) were similar $(\mathrm{P}>0.05)$ for all group, while the Albumin, Globulin, Cholesterol, Aspartate aminotransferase (AST) and Alanine aminotransferase (ALT) were influence by dietary treatments $(\mathrm{P}<0.05)$. Albumin values ranges from 5.83 to 7.68 with rats on T4 having the highest albumin value (7.68)

Globulin value for rats on $\mathrm{T} 4$ is significantly $(\mathrm{P}>0.05)$ different from rats on $\mathrm{T} 1, \mathrm{~T} 2, \mathrm{~T} 3$, and $\mathrm{T} 5$ with rats on $\mathrm{T} 3$ having the highest value (3.42). Rats on T1 had the highest Cholesterol (55.37) and SGPT (17.49) value while Rats on T2 had the highest AST (16.13) value.

Kidney weight were similar for all group $(\mathrm{P}>0.05)$ while the liver, lungs and heart weight were significantly affected $(\mathrm{P}<0.05)$ by dietary treatments. Rats on control diet had the lowest weight for liver (3.74), lungs (1.03), kidney (0.92) and heart (0.49). Rats on T3 and T5 had the highest value for heart weight (0.75) and liver weight (5.67) while rats on T4 had the highest value for lungs (1.59).

Packed cell volume is an index of toxicity, any reduction in its concentration in the blood usually would suggest presence of

Table 2. Determined proximate composition and fibre fraction of experimental diets

\begin{tabular}{lccccccccc}
\hline Treatments & DM & CP & EE & Ash & CF & NFE & NDF & ADF & ADL \\
\hline Control diet & 90.10 & 14.30 & 5.70 & 4.60 & 7.37 & 58.13 & 32.50 & 6.14 & 1.25 \\
Soaked in ogi liquor & 91.40 & 10.30 & 4.80 & 5.30 & 7.37 & 63.6 & 57.40 & 8.39 & 1.24 \\
Soaked in lye solution & 88.70 & 16.90 & 7.10 & 6.60 & 7.04 & 51.1 & 5.90 & 6.15 & 8.62 \\
Boiling for 15minutes & 90.00 & 14.50 & 5.70 & 5.00 & 7.34 & 53.50 & 25.60 & 6.90 & 2.27 \\
Negative control & 88.90 & 3.09 & 8.50 & 3.60 & 7.72 & 65.9 & 17.9 & 6.59 & 1.24 \\
\hline
\end{tabular}

DM-dry matter, CP-crude protein, EE-ether extract, CF-crude fibre, NFE-nitrogen free extract, NDFneutral detergent fibre, ADF-acid detergent fibre, ADL-acid detergent lignin 
Table 3: Haematological profile of Wistar rat fed processed jack bean

\begin{tabular}{|c|c|c|c|c|c|c|}
\hline Parameter & T1 & $\mathbf{T 2}$ & T3 & $\mathbf{T} 4$ & T5 & SEM \\
\hline $\mathrm{PCV}(\%)$ & $46.00^{\mathrm{a}}$ & $39.00^{\mathrm{b}}$ & $45.00^{\mathrm{ab}}$ & $47.00^{\mathrm{a}}$ & $41.33^{\mathrm{ab}}$ & 2.00 \\
\hline Haemoglobin (g/100ml) & 15.32 & 13.00 & 14.32 & 15.00 & 13.80 & 0.79 \\
\hline $\mathrm{RBC}\left(10^{6} / \mathrm{mm}^{3}\right)$ & $5.95^{\mathrm{a}}$ & $5.41^{\mathrm{a}}$ & $3.88^{\mathrm{b}}$ & $4.90^{\mathrm{ab}}$ & $5.28^{\mathrm{a}}$ & 0.36 \\
\hline $\mathrm{WBC}\left(\mathrm{x} 10^{3} / \mathrm{mm}^{3}\right)$ & 6.37 & 6.08 & 6.08 & 5.46 & 5.43 & 0.47 \\
\hline Lymphocytes (\%) & $75.67^{\mathrm{ab}}$ & $80.33^{\mathrm{a}}$ & $74.50^{\mathrm{ab}}$ & $73.25^{\mathrm{b}}$ & $74.25^{\mathrm{ab}}$ & 1.98 \\
\hline Neutrophils (\%) & $21.33^{\mathrm{dc}}$ & $18.33^{\mathrm{d}}$ & $21.67^{\mathrm{bc}}$ & $25.67^{\mathrm{a}}$ & $24.67^{\mathrm{ab}}$ & 1.03 \\
\hline Monocytes (\%) & $3.00^{\mathrm{ab}}$ & $3.50^{\mathrm{a}}$ & $2.00^{\mathrm{b}}$ & $3.00^{\mathrm{ab}}$ & $2.67^{\mathrm{ab}}$ & 0.35 \\
\hline Eosinophils (\%) & 0.25 & 1.25 & 0.50 & 1.00 & 1.00 & 0.61 \\
\hline $\operatorname{MCV}(f l)$ & $0.78^{b}$ & $0.77^{\mathrm{b}}$ & $1.57^{\mathrm{a}}$ & $0.81^{\mathrm{b}}$ & $0.72^{b}$ & 0.12 \\
\hline $\mathrm{MCH}(p g)$ & $0.26^{\mathrm{b}}$ & $0.24^{\mathrm{b}}$ & $0.40^{\mathrm{a}}$ & $0.27^{\mathrm{b}}$ & $0.23^{\mathrm{b}}$ & 0.02 \\
\hline MCHC (gm/100ml) & 33.33 & 33.33 & 33.33 & 33.33 & 33.37 & 0.03 \\
\hline
\end{tabular}

Table 4: Serum biochemical indices of Wistar rat fed processed jack bean

\begin{tabular}{lllllll}
\hline Parameters & T1 & T2 & T3 & T4 & T5 & SEM \\
\hline Total protein(g/dl) & 10.4 & 10.05 & 9.42 & 9.71 & 9.86 & 0.56 \\
Albumin(g/dl) & $5.83^{\mathrm{b}}$ & $7.43^{\mathrm{a}}$ & $7.04^{\mathrm{a}}$ & $7.68^{\mathrm{a}}$ & $5.88^{\mathrm{b}}$ & 0.27 \\
Globulin(g/dl) & $3.37^{\mathrm{a}}$ & $3.38^{\mathrm{a}}$ & $3.42^{\mathrm{a}}$ & $2.30^{\mathrm{b}}$ & $2.95^{\mathrm{a}}$ & 0.21 \\
Cholesterol(mg/dl) & $55.37^{\mathrm{a}}$ & $38.33^{\mathrm{c}}$ & $49.52^{\mathrm{ab}}$ & $42.73 \mathrm{~b}^{\mathrm{c}}$ & $51.23^{\mathrm{ab}}$ & 2.92 \\
ALP $(I U / L)$ & 105.55 & 107.28 & 135.98 & 133.60 & 107.30 & 25.8 \\
AST $(I U / L)$ & $14.57^{\mathrm{ab}}$ & $16.13^{\mathrm{a}}$ & $12.18^{\mathrm{c}}$ & $13.16^{\mathrm{bc}}$ & $13.11^{\mathrm{bc}}$ & 0.73 \\
ALT $(I U / \mathrm{L})$ & $17.49^{\mathrm{a}}$ & $16.53^{\mathrm{ab}}$ & $16.95^{\mathrm{ab}}$ & $15.30^{\mathrm{b}}$ & $12.57^{\mathrm{c}}$ & 0.63 \\
\hline
\end{tabular}

$\overline{a, b, c}$ Means with different superscript on the same row are significantly different $(\mathrm{P}>0.05)$

SEM-Standard error of mean, ALP-Alkaline phosphatase, Aspartate aminotransferase (AST) and Alanine aminotransferase(ALT)

Table 5: Relative organ weight of Wistar rats fed processed jack bean

\begin{tabular}{lllllll}
\hline Organ & T1 & T2 & T3 & T4 & T5 & SEM \\
\hline Liver & $3.74^{\mathrm{b}}$ & $4.81^{\mathrm{a}}$ & $5.13^{\mathrm{a}}$ & $5.27^{\mathrm{a}}$ & $5.67^{\mathrm{a}}$ & 0.28 \\
Lungs & $1.04^{\mathrm{b}}$ & $1.06^{\mathrm{b}}$ & $1.54^{\mathrm{a}}$ & $1.59^{\mathrm{a}}$ & $1.29^{\mathrm{ab}}$ & 0.07 \\
Kidney & 0.92 & 0.93 & 1.77 & 1.11 & 0.97 & 0.25 \\
Heart & $0.49^{\mathrm{b}}$ & $0.55^{\mathrm{ab}}$ & $0.75^{\mathrm{a}}$ & $0.63^{\mathrm{ab}}$ & $0.59^{\mathrm{ab}}$ & 0.05 \\
\hline
\end{tabular}

${ }^{\mathrm{a}, \mathrm{b}}$ means on the same row but with different superscripts are significantly $(\mathrm{P}<0.05)$ different. 
toxic factors (haemagglutinins) which has adverse effect on blood formation (Oyawole and Ogunkunle, 1998). The PCV values recorded for various treatment groups could be viewed as coefficient of efficiency of various processing methods in reducing the ANFs. The higher the value, the more capable the method. This implies that jack bean boiled for 15 minutes based diet compare favourably with the control diet. Red blood cells values of rats on control diet and negative control (protein free diet) were significantly $(\mathrm{P}<0.05)$ different from rats on Diet 4 (boiling for 15 minutes). The observed decrease in red blood cell value of rats on $\mathrm{T} 3$ and $\mathrm{T} 4$ could be attributed to the destruction of RBC cells by the residual antnutritional factor and toxicants. This agrees with the findings of (Oyawole and Ogunkunle, 1988) who reported that biochemical components of blood are sensitive to element of toxicity in feed. However, haematological components are also valuable in monitoring feed toxicity especially with feed constituent that affects the formation of blood. This confirms the poor ability of rats on $\mathrm{T} 3$ and $\mathrm{T} 4$ to support blood formation and eventually leading to poor growth. The non-significant $(\mathrm{P}>0.05)$ difference in white blood cells suggested that there is no microbial infection or the presence of foreign body or antigen in the circulatory system.

The values obtained for $\mathrm{MCV}$ and $\mathrm{MCH}$ followed a similar trend with the values being the highest for rats on T3, the values suggest nutritional inadequacy of the diet. Total protein was not influence by dietary treatment which suggested that the health status of the rats was better for the tested diet as they compare favourably with control. The globulin values of rats on $\mathrm{T} 1$, $\mathrm{T} 2, \mathrm{~T} 3$ and $\mathrm{T} 5$ were significantly $(\mathrm{P}<0.05)$ different from rat on $\mathrm{T} 4$, this signified the ability of rats in the treatments to fight against infections

The statistical similarities observed for rats on T1, T2, T3, and T4 for ALT, suggested that there was no necrosis and myocardial infection which agrees with the findings of (Fasina et al., 1999) who reported that increase in AST and ALT signal necrosis and myocardial infection which are indications of poor protein in the diet.

The statistical $(\mathrm{P}<0.05)$ difference in liver weight for rats on T2, T3, T4 and T5 when compared with rats on $\mathrm{T} 1$ could be attributed to the effect of processing on the anti-nutrients. The liver and the kidney are major detoxifying organs, hence enlargement and increase in weight as a result of increase in activity of the organs to detoxify residual anti-nutrient (Ologhobo et al., 1993, Ukachuku, 2000). The control diet provided the liver with enough protein for deamination and other functions while there was an enlargement in the liver of rat fed processed jack bean diets. Akanji et al., 2003 reported that any processing methods that could not completely remove trypsin inhibitors actively could also not lead to complete removal of haemaglutinins (con canavanine A) a heat stable anti-nutrients and of course canavanine another related heat stable anti-nutrients. Canavanine has been reported to cause liver hypertrophy, it interfere with normal production of liver proteins impairing liver functioning and producing hypertrophic effect leading to an increase in weight (Oyawole et al., 1999). Rats on $\mathrm{T}_{5}$ had the highest value of liver weight $(5.67 \%)$ this might be due to excess carbohydrate in the body which yield higher glucose molecules which is converted to glycogen during glycogenesis, and might lead to build up of fat in the liver adding to the weight of the liver observed in rat fed T5. it was observed that the kidney was not influence by dietary treatments, although 
rats on $\mathrm{T}_{3}$ had highest kidney weight $(1.77 \%)$ which indicated the diet fed has a higher content of ANF present, the increase in weight of the kidney agrees with the report of Ologhobo et al., 1993 who reported increase in the weight of kidney of broiler fed raw lima bean and this was attributed to the fact that the key enzyme in cyanide detoxification is located mainly in the kidney therefore the increase activity of the kidney might have led to an increase. Ahamaefule et al., 2006 also reported that weights of some internal organs like kidney, lungs, liver of animal may be used in animal feeding experiment as evidence of toxicity. Hence, presence of some anti-nutritional compounds could account for the increase liver weight in an attempt to detoxify them. Rats on T4 had the highest lungs weight (1.59) while rats on T3 had the highest heart weight (0.55) this suggest that anti-nutrients present was able to cause observable damage to the lungs and heart for rats on T3 and $\mathrm{T} 4$ respectively

In conclusion dehulled jack bean seeds soaked in ogi liquor when fed to rats showed slight improvement on haematological parameters, serum biochemistry and organ weight changes of the animal when compared to those fed lye based diets and boiled for 15 minutes. However, all the processing methods showed poor results on rats when compared to the rats fed casein-based diet. Long duration of soaking in filtrate obtained from steeped whole maize grains for more than 24 hours may possibly improve haematological, serum biochemistry and organ weight changes of rats.

\section{References}

Akanji A. M., Ologhobo, A. D., Emiola, I. A. and Adedeji, O. S. 2003. The effects of various processing on haemagluttins and other anti- nutritional factors in jack bean Proceedings of $28^{\text {th }}$ Annual Conference of NSAP held at I. A. R. \& T. Ibadan, $16^{\text {th }}-20^{\text {th }}$ March 2003, pp. 189-193.Editors: A. A. Taiwo, A. M. Raji, J. U. Ogbonna and E. A. Adebowale.

Ani, A. O. and Adiegwu, L. U. 2005. Feeding value of velvet beans (Mucuna pruriens) to weaner rabbits. Proceeding of the $30^{\text {th }}$ annual conference of Nigeria Society for Animal Production held at the University of Nigeria Nsukka $20^{\text {th }}-24^{\text {th }}$ march, 2003.pp 186-189.

Amaefule, K. U. and Nwagbara, N. N. 2004. Effect of Processing on Nutrient Utilization of Pigeon pea (Cajanus cajan) Seed Meal Based Diets by Pullets. International Journal of Poultry Science. 3 (8): 543-546

Amaefule, K. U, Ironkwe, M. O. and Ojewola, G. S. 2006. Performance of grower pullets fed raw or processed pigeon pea seed meal diets. International Journal of Poultry Science. 5(1): 60-64

Arora S. K. 1995. Composition of legume grain. In D Mello J. P. F. and Devendra C. (eds), Tropical legumes in Animal nutrition, pp 67-93 CABI, UK.

D'Mello, J. P. F. 1995a. Anti-nutritional substances in legume seeds, In: D'Mello, J. P. F. And Devendra C. (eds) Tropical legumes in Animal nutrition, pp 135-172 CABI.UK.

D'Mello, J. P. F. 1995b. Under - utilized legume grains in non-ruminant nutrition. In :D'Mello, J.P. F. And Devendra C. (eds) Tropical legumes in Animals nutrition, pp.283- 329. 


\section{CABI.UK.}

Fasina, O. E, Ologhobo A. D, Ayoade G. O, Adenira G. A, Adeyemi O. A.1999. Nutritional and toxicological assessment of various Amyadalin leaf meal in nutrition of broilers chicks: Effect on Performance, haematological and biochemical indices. Proceedings of Annual Conference of Animal Science Association of Nigeria 4: 19-22

Fasuyi, A. O. 2005. Nutrient composition and processing effects on cassava leaf (Manihot esculenta, Crantz) antinutrients. Pakistan Journal of Nutrition. 4 (1): 37-42.

Ologhobo, A. D., Apata, D. F. and Oyejide, A. 1993.Utilization of raw jack bean(Canavalia ensiformis) and jackbean fractions in diets for broiler chicks. British Poult. Science, 34: 323-337.

Oyawoye E. O and Ogunkunle M. 1998. Physiological and biochemical effects of raw jack beans on broilers. Proceedings of annual Conference of Nigerian Society of Animal Production. 23: 141-142.

Oyawole E. O. Ogunkunle N. O.,
Bamgbose, A. M. and Tabiyi, K. E. 1999. Response of broiler to heat treated jack bean (Canavalia ensiformis). Nigeria Society for Animal Production (NSAP) proceedings, Ilorin 259-262,

SAS, 1999. Statistical Analytical Systems. User's guide. Version6. $3^{\text {rd }}$ edition. Cary. North. Carolina. USA. 943.

Siddhuraju, P. and Becker, K. 2001. Species/variety differences in biochemical composition and nutritional values of Indian tribal legumes of genus Canavalia. Nahrung 45, 224-233

Udedibie, A. B. I. and Carlini, C. R. 1998. Questions and answers to edibility problem of Canavalia ensiformis seeds a review. Animal Feed Science Technology, 74:95-106

Ukachukwu S. N., 2000. Chemical and Nutritional evaluation of Mucuna coclinchinesis (lyons bean) as a alterative protein ingredients in broiler diets Ph.D Thesis University of Nigeria, Nsukka, 5-37

Received: $15^{\text {th }}$ April, 2014 Accepted: $20^{\text {th }}$ February, 2015 